\title{
Panel: OASIS in the Mirror: Reflections on the Impacts and Research of IFIP WG 8.2
}

\author{
Kenneth E. Kendall ${ }^{1}$ (panel chair), David Avison ${ }^{2}$, \\ Gordon Davis ${ }^{3}$, Julie E. Kendall ${ }^{4}$, Frank Land ${ }^{5}$, and \\ Michael D. Myers ${ }^{6}$ \\ ${ }^{1}$ Rutgers University, US, ken@thekendalls.org \\ ${ }^{2}$ ESSEC Business School, France, avison@essec.fr \\ ${ }^{3}$ University of Minnesota, US, gdavis@csom.umn.edu \\ ${ }^{4}$ Rutgers University, US, julie@thekendalls.org \\ ${ }^{5}$ London School of Economics and Political Science, UK, \\ FLandLSE@aol.com \\ ${ }^{6}$ University of Auckland, NZ, m.myers@, auckland.ac.nz
}

\begin{abstract}
What has IFIP contributed to the field of information systems and organizations through the activities of Working Group 8.2, its central working group in information systems? What has WG 8.2 delivered to its constituents? What have the results and impacts of the WG 8.2 been on the larger community? This panel will not shy away from controversy as it discusses the history, contributions, and unrealized potential of research spawned by this working group over the past 30 years.
\end{abstract}

\section{Introduction}

The central IFIP working group in information systems is IFIP Working Group 8.2. OASIS is the acronym adopted by Working Group 8.2 to stand for Organizations and Society in Information Systems. One definition of oasis refers to it as a fertile spot in a desert or wasteland. Another definition implies that an oasis is a retreat or place of refuge from unpleasant or chaotic surroundings. Working Group 8.2 titles its semiannual newsletter as "OASIS" as well as calling its informal workshops preceding ICIS meetings "OASIS."

What has IFIP contributed to the field of information systems and organizations through the activities of Working Group 8.2, its central working group in 
information systems? What has WG 8.2 delivered to its constituents? What have the results and impacts of the WG 8.2 been on the larger community?

Within the foregoing framework of this broad topic, this panel of past and present chairs of WG 8.2, and past and present IFIP officers and national representatives, will discuss the nature, methodologies, and direction of research related to the interaction of organizations and society with information systems and IT from inception of the working group until the present.

The panel will engage in debate on some of the hallmark debates resonating through IS and WG 8.2 including the relative merits of qualitative versus quantitative research; the question of rigor versus relevance; and whether technical or nontechnical approaches are superior.

Questions to be examined by the panel also include: Has the research originating from WG 8.2 members been fertile? Has WG 8.2 visibly altered the academic landscape? Or are the premier journals, deans of business schools, and junior faculty in IS still taking conservative (or safe) approaches identical to those held prior to the inception of Working Group 8.2? Additionally, have we been inclusive or exclusive in the way we accept innovative ideas, paradigms, methodologies, tools or even IS researchers?

Among the participants in this panel are four Past Chairs WG 8.2, a Past Chair of TC8, and the Current Chair of WG 8.2.

\section{About the Panelists}

Kenneth E. Kendall, Ph. D., (panel chair) is a professor of ecommerce and information technology in the School of Business-Camden, Rutgers University. He is one of the founders of the International Conference on Information Systems (ICIS) and a Fellow of the Decision Sciences Institute (DSI). He is currently the PresidentElect of DSI and a Past Chair of WG 8.2. Dr. Kendall has been named as one of the top 60 most productive MIS researchers in the world and recently co-authored a text, Systems Analysis and Design, sixth edition and Project Planning and Requirements Analysis for IT Systems Development. Dr. Kendall has had his research published in MS Quarterly, Management Science, Operations Research, Decision Sciences, Information \& Management, CAIS and many other journals. For his mentoring of minority doctoral students in information systems, he was named to the Circle of Compadres of the Ph.D. Project, which was begun by the KPMG Foundation a decade ago to increase the diversity of business school faculty. Professor Kendall's research focuses on studying push and pull technologies, ecommerce strategies, and developing new tools for systems analysis and design. His email is ken@thekendalls.org.

Dr. David Avison is Professor of Information Systems at ESSEC Business School, Paris, France after being Professor at the School of Management at Southampton University for nine years. He is joint editor of Blackwell Science's Information Systems Journal. He has over twenty books to his credit (plus one translation from 
the French). Recently he published four books, including the third edition of the text Information Systems Development (jointly with Guy Fitzgerald). He has published a large number of research papers in learned journals, edited texts, and conference papers. He served as vice chair of IFIP technical committee 8 and was past Chair of IFIP WG 8.2. He was past President of the UK Academy for Information Systems and also chair of the UK Heads and Professors of IS. Recently he was a Program Chair of ICIS 2005 in Las Vegas. He researches in information systems development and on information systems in their natural setting, in particular using action research, though he has also used a number of other qualitative research approaches. His email is avison@essec.fr.

Gordon B. Davis is the Honeywell Professor of Management Information Systems at the Carlson School of Management, University of Minnesota. He received his MBA and Ph.D. from Stanford University. He also holds honorary doctorates from the University of Lyon, the University of Zurich, and the Stockholm School of Economics. He is a Fellow of the Association for Computing Machinery. He is the U.S.A. representative of IFIP Technical Committee 8 (Information Systems) and has served as chairman of TC8. He serves on the editorial boards of major journals in the field. He has published extensively and written 20 books in the MIS area. His areas of research include MIS planning, information requirements determination, conceptual foundations for IS, control and audit of information systems, quality control for user-developed systems, in-context assessment of information systems, and management of knowledge work. Gordon can be reached by e-mail at gdavis@csom.umn.edu.

Julie E. Kendall, $\mathrm{Ph}$. D., is an associate professor of ecommerce and information technology in the School of Business-Camden, Rutgers University. Dr. Kendall is the immediate Past Chair of IFIP Working Group 8.2 and was awarded the Silver Core from IFIP. Professor Kendall has published in MIS Quarterly, Decision Sciences, Information \& Management, CAIS, Organization Studies and many other journals. Additionally, Dr. Kendall has recently co-authored textbook, Systems Analysis and Design, sixth edition. She is also a co-author of Project Planning and Requirements Analysis for IT Systems Development. She co-edited the volume Human, Organizational, and Social Dimensions of Information Systems Development published by North-Holland. Dr. Kendall is a Senior Editor for JITTA and is on the editorial boards of the Journal of Database Management and IRMJ and was Co-Coordinator of the DSI Doctoral Student Consortium in 2003. She also serves on the review board of the Decision Sciences Journal of Innovative Education and was a functional editor of MIS for Interfaces and an associate editor for MIS Quarterly. Dr. Kendall is researching policy formulation for ICTs in developing countries, and agile methodologies for systems development. Her email is julie@thekendalls.org.

Frank Land received his Bsc (Econ) from the London School of Economics in 1950. In 1952, he joined J. Lyons, the UK food and catering company that pioneered the use of computers for business data processing, building its own computer, the LEO (Lyons Electronic Office). He stayed with LEO until 1967 when he was invited to establish teaching and research in information systems at the London School of 
Economics. In 1982, he was appointed Professor of Systems Analysis. In 1996, he became Professor of Information Management at the London Business School. On his retirement in 1992, he was appointed Visiting Professor of information Management at the LSE. Frank is a past Chairman of IFIP WG 8.2. He can be reached by e-mail at FLandLSE@aol.com.

Michael D. Myers is a Professor of Information Systems in the Department of Management Science and Information Systems at the University of Auckland, New Zealand. He is currently the Chair of IFIP Working Group 8.2 and President-Elect of AIS. Michael has published widely in the areas of qualitative research methods, interpretive research, ethnography, and information systems implementation. He is editor of the ISWorld Section on Qualitative Research, senior editor of MIS Quarterly, an associate editor of Information Systems Journal, and Editor in Chief of the University of Auckland Business Review. Michael can be reached by e-mail at m.myers@auckland.ac.nz. 